\title{
Correction to: Communication processes in intercultural transdisciplinary research: framework from a group perspective
}

\author{
Jue Wang ${ }^{1}\left[\right.$. Thomas Aenis ${ }^{1} \cdot$ Tuck Fatt Siew $^{2}$
}

Published online: 27 July 2019

(c) The Author(s) 2019

\section{Correction to: Sustainability Science https://doi.org/10.1007/s11625-019-00661-4}

The article Communication processes in intercultural transdisciplinary research: framework from a group perspective, written by Jue Wang, Thomas Aenis and Tuck Fatt Siew, was originally published electronically on the publisher's internet portal (currently SpringerLink) on 11 February 2019 without open access.

With the author(s)' decision to opt for Open Choice the copyright of the article changed on 25 July 2019 to $($ ) The Author(s) 2019 and the article is forthwith distributed under the terms of the Creative Commons Attribution 4.0 International License (http://creativecommons.org/licen ses/by/4.0/), which permits use, duplication, adaptation, distribution and reproduction in any medium or format, as long as you give appropriate credit to the original author(s) and the source, provide a link to the Creative Commons license and indicate if changes were made.

The original article has been corrected.

Open Access This article is distributed under the terms of the Creative Commons Attribution 4.0 International License (http://creativeco mmons.org/licenses/by/4.0/), which permits unrestricted use, distribution, and reproduction in any medium, provided you give appropriate credit to the original author(s) and the source, provide a link to the Creative Commons license, and indicate if changes were made.
The original article can be found online at https://doi.org/10.1007/ s11625-019-00661-4.

Jue Wang

juewang0312@gmail.com

1 Albrecht Daniel Thaer-Institute of Agricultural and Horticultural Sciences, Humboldt-Universität zu Berlin, Luisenstr. 53, 10099 Berlin, Germany

2 Institute of Physical Geography, Goethe University Frankfurt, Altenhöferallee 1, 60438 Frankfurt am Main, Germany 